Covered in: ERIH PLUS, CEEOL, Index Copernicus, CrossRef, CrossCheck, J-Gate, Google Scholar, Ideas RePeC, Econpapers, Socionet, KVK, WorldCat.

2018, Volume 6, Issue 1, pages: 36-38 | doi: https://doi.org/10.18662/lumenphs/05

\section{Review for the} volume

"Reglementarea juridică a funcţiei publice în statele europene", author Razvan Viorescu, published in 2015 by LUMEN Publishing

\section{House}

\section{Alexandra HUIDU1}

${ }^{1}$ PhD Student, Doctoral School of Sociology, University of Oradea, Romania; LUMEN Research Center in Social and Humanistic Sciences, Iasi, Romania.

\begin{abstract}
The volume "Reglementarea juridică a funcției publice în statele europene" |The Legal Regulation of the Public Service in the European States] is not only a topical issue, a synthesis of the issue around the public servant, with all controversies raised by this statute, but also brings o double analysis of comparative law. On one side, it is a classic analysis between the legislations of many states, with an emphasis - as the title suggests - on the member states of the European Union. Secondly, the comparative analysis also targets the parallelism between the system of regulation of the public service in the states of the European Union, influenced by the European regulations and the system of regulation of the public service in a non-EU state - the Republic of Moldova. In other words, the analysis of comparative law is made both from inside the system analysed, as well as externally, which offers a new and unique perspective in the Romanian doctrine.
\end{abstract}

Keywords: legal regulation; law; European states; public service;

How to cite: Huidu, A. (2018). Review for the volume "Reglementarea juridică a funcției publice în statele europene", author Razvan Viorescu, published in 2015 by LUMEN Publishing House. Logos Universality Mentality Education Novelty: Philosophy \& Humanistic Sciences, 6(1), 36-38. https://doi.org/10.18662/lumenphs/05 
We didn't notice the author excluding from the analysis any topic of interest for the subject. Moreover, the volume is an interesting combination of administrative law and community law, and from this point of view and the way of tackling the topic, it stands out as the first work of this kind exclusively dedicated to the public service in the Romanian scientific literature, an extended work, seriously documented, that addresses all notions of interest in the field.

The analysed volume addresses the matter of public service and public servant in a correlated and unitary way, not disparate or incidental, as it is customary in the Romanian doctrine, only through punctual studies (scientific articles) or simple chapters in treaties and monographs (the latter ones focusing on other main themes), in works whose main purpose was not this subject and which only scarcely approached it or haven't dedicated it a whole space of analysis the subject would have deserved. The fact that the author writes this monograph in a field that is new to law - the comparative administrative law - is in line with the tendencies in the international legal literature.

We notice the clarity with which the author has structured the manuscript in order to adapt it to the title of the volume. Thus, Chapter 1 focuses on the concepts analysed from the perspective of national comparative law, Chapter 2 brings the comparative analysis between the right of the EU states and the system of law in the Republic of Moldova - a non-European state -, and Chapter 3 correlates the two previous chapters with the community administrative law and the community specific regulations in the matter of European public service. In the separate chapter of Conclusions, inserted at the end of the manuscript, the author reiterates and emphasizes again the main arguments his scientific discourse has brought along the volume, making a good synthesis.

Not only do we not identify, in this monograph, a subject that is superficially addressed, or for that matter, subjects that are given special attention that exceeds the framework of the paper, but we insist on the good organization of the manuscript, as previously shown, and the good way in which the author chose to address all notions involving the analysis of the public service in the national legislation, in that of other states, as well as in the legislation of the EU, concluding, offering solutions, proposals of lege ferenda and valuable analysis.

The double analysis of comparative law is, with certainty, the most important strength of this manuscript. Then, there is the courage of the author to bring into attention a branch of law in emergence, more precisely the European administrative law, and to treat it, with solid arguments, as an 
autonomous branch, with all consequences drifting from it, although in the legal literature there are still debates on the topic.

The author has the courage to discuss the concepts in the volume not in the past and for clarifying the past, but for the future, to push the analysis beyond the traditional ideas and to provoke to discussions. All this attempt involved elaborating the work in an extensive manner. Maybe the subjects could have been synthesized in a less extensive analysis, or it sometimes seems that the author tries to make an exhaustive approach to the main subject and the subjects correlated to it, but in reality we consider that the approach proposed is the best way to scientifically present a topic in which the need for evolution is felt firstly at the level of the doctrine, so that it would then translate into practice.

We appreciate that the manuscript addresses a wide category of readers. On one side there are the jurists, mostly theoreticians, and on the other hand there are all the officials involved in public administration, as well as the members of the leadership organs of the structures of local and central public administration. Thus, the monograph does not only address the direct beneficiaries of a collection of legal books, but also other potential stakeholders, which makes the paper even more valuable and of interest.

The organization of the manuscript is clear and perfectly merges with the objectives of the research proposed by the author. These objectives are the approach of the public service from the perspective of comparative law (Chapter 1), from the perspective of European law (Chapter 3), from the perspective of internal law and the correlation of national legislations with European regulations (Chapter 2). The way of organizing the analysis is well chosen and it highlights the concepts under review.

We notice not only the extremely extended bibliography, but also the fact that the volume abounds in citing some foreign authors, and not only the classics in the field. The author brings forward the French, British, German and Italian doctrines, consistent web sources, makes reference to the classic Romanian doctrine, but also to the recent one, correlating them and making the most out of them.

The monograph reviewed is a complex work, well-structured and augmented at the level of scientific research, with solid bibliography. We notice the author's topical intervention with opinions and personal points of view, with proposals of lege ferenda and necessary clarifications. It is a synthesis of concepts, an analysis of legislation but also a launching ramp for future discussions. An original work, bold in certain segments, which makes reading pleasant and interesting. 
The book focuses on a topical theme, addresses a wide audience, is scientifically correct, brings elements of novelty in the research in the field, and conducts an optimal analysis of the subjects in matter. It is a study the author has clearly put a lot of work into, and this emerges from the quality of the writing and the depth of the research.

\section{Acknowledgement}

This paper was elaborated within the doctoral research entitled "Social and Bioethical Acceptance of Techniques Related to Medically Assisted Human Reproduction in Romania", within and with funding by the doctoral scholarship awarded by the Doctoral School of Sociology, University of Oradea, Romania. The research is carried out in cocoordination with the University of Medicine and Pharmacy Grigore T. Popa from Iasi, Romania.

\section{References}

Viorescu, R. (2015). Reglementarea juridică a funcției publice în statele europene. Iasi, Romania: LUMEN Publishing House. 